\title{
Effects of eelgrass beds on advection and turbulent mixing in low current and low shoot density environments
}

\author{
S. E. Worcester* \\ Department of Integrative Biology, University of California, Berkeley, California 94720, USA
}

\begin{abstract}
The effects of eelgrass Zostera marina beds on the rates of horizontal transport (advection) and turbulent mixing in the water column were measured in the field. The dye-tracking technique used in this study directly measures mixing within the canopy rather than estimating mixing from velocity profiles. Tomales Bay, California, and False Bay, Washington, USA, were characterized by slow currents (generally $<0.05 \mathrm{~m} \mathrm{~s}^{-1}$ ) and low shoot densities (100 to 200 shoots $\mathrm{m}^{-2}$ ). At these sites, the eelgrass canopy reduced advection, but had no effect on turbulent mixing relative to areas without eelgrass. At sites that had nearly continuous eelgrass cover, there was greater advection and mixing above the eelgrass canopy than there was at the same height in the water column over bare substratum. In contrast, sites with discrete eelgrass beds surrounded by sand showed no evidence of such accelerated flow over the canopy. In addition, the eelgrass canopy damped out the variations in advection and mixing due to wind and tidal currents that occurred in adjacent areas without eelgrass. Previous studies have focused on the effects of seagrasses on flow in relatively fast currents (typically $>0.10 \mathrm{~m} \mathrm{~s}^{-1}$ ) and high shoot densities $\left(>400\right.$ shoots $\mathrm{m}^{-2}$ ). This study has shown that only parts of the paradigm from these previous studies holds in sluggish flow and sparse grass (i.e. reduced advection within the canopy) whereas other parts of the paradigm differ (i.e. turbulence within the canopy)
\end{abstract}

KEY WORDS: Zostera marina Eelgrass Mass transport - Turbulent muxing Hydrodynamics Canopy

\section{INTRODUCTION}

Underwater canopies of vegetation, such as seagrasses and kelps, modify ambient currents (see review by Koehl 1986). Such flow modification can have important effects on the organisms within these canopies by altering the flux of gases and nutrients (e.g. Koehl \& Alberte 1988, Carpenter et al. 1991, Carpenter \& Williams 1993, Koch 1993), the supply of food to suspension-feeders (e.g. Eckman \& Duggins 1991. Irlandi \& Peterson 1991), and the dispersal of propagules such as gametes, larvae and spores (e.g. Bernstein \& Jung 1979, Worcester unpubl.).

Seagrass canopies are important components of estuarine ecosystems. Not only do seagrasses provide habitats for a vast number of organisms (e.g. Wood et

\footnotetext{
- Present address: Marine Science Institute, University of California, Santa Barbara, California 93106, USA. E-mail worceste@lifesci.lscf.ucsb.edu
}

al. 1969, Heck \& Orth 1980, Orth et al. 1984, Edgar 1990), but they also stabilize sediments (e.g. Ginsburg \& Lowenstam 1958, Scoffin 1970, Orth 1977, Fonseca \& Fisher 1986).

Since many estuarine species occur within seagrass beds and since many biologically important processes are affected by flow modification within canopies, an understanding of flow through seagrass beds across the range of flow regimes the plants experience is needed. Previous field studies on flow through seagrass canopies have focused on habitats with relatively fast current regimes (usually $>30 \mathrm{~cm} \mathrm{~s}^{-1}$ ) and/or dense stands of plants $\left(>400\right.$ shoots $\mathrm{m}^{-2}$ ) (e.g. Scoffin 1970 , Fonseca et al. 1982, 1983, Eckman 1987). These studies have found substantial reductions in flow within seagrass canopies. However, seagrasses often occur in sluggish currents and sparse stands, and it is unknown whether seagrasses have the same flow modification effects in such habitats. In addition, previous studies have focused on velocity profiles as a measure of the 
effect of seagrasses on water motion (Fonseca et al. 1982, 1983, Peterson et al. 1984, Ackerman 1986, Eckman 1987. Gambi et al. 1990, Ackerman \& Okubo 1993, Koch 1993). Such measurements are instantaneous at a point in space and provide only an indirect measure of biologically important mass transport processes such as the movement of gases, wastes, nutrients, or propagules. Mass transport can be assessed directly by tracking the motion of dye-marked water within and between eelgrass beds.

Using a technique developed by Koehl et al. (1987. 1988, 1993). I measured the rate of horizontal transport (advective velocity) and mixing (horizontal mixing coefficient) on a spatial scale of tens of centimeters to meters by tracking boluses of dye-marked water inside and outside of eelgrass canopies. I compared the effect of eelgrass canopies on mass transport in 2 bays with sluggish currents (typically $<0.05 \mathrm{~m} \mathrm{~s}^{-1}$ ) and sparse eelgrass stands $\left(<200\right.$ shoots $\left.\mathrm{m}^{-2}\right)$ : Tomales Bay, California, and False Bay, Washington, USA.

Previous studies have found reduced velocities within seagrass canopies and increased velocities above seagrass canopies (skimming flow, sensu Morris 1955) relative to ambient flow (Molinier \& Picard 1952, Ginsburg \& Lowenstam 1958, Scoffin 1970, Fonseca et al. 1982, 1983, Ackerman 1986, Gambi et al. 1990, Koch 1993). I compared mass transport within and above eelgrass canopies with ambient flow at the same heights above the substratum outside eelgrass to learn whether similar results would be observed in sparse stands of eelgrass occurring in slow flow habitats. In addition, in intertidal eelgrass beds the canopy can fill the entire water column during portions of the tidal cycle. I tested whether the effect of eelgrass on ambient flow would be greater when the water depth is less than the canopy height relative to when the water depth exceeds the canopy height.

At the low current velocities at these study sites, the shoots would be expected to bend little in response to flow, unlike previous studies in faster flow (e.g. Scoffin 1970, Fonseca et al. 1982, 1983). The eelgrass canopies in sluggish currents may provide a greater resistance to water movement because of the greater surface area perpendicular to flow than eelgrass canopies in fast flow which bend over, redirecting the flow over and under the canopy. If these eelgrass canopies in sluggish currents increase resistance to flow, then water would tend to be diverted around beds, and thus flow directly downstream from beds would be reduced. To test this hypothesis, I compared mass transport in 2 eelgrass beds, one that was downstream from a nearby grass bed and another that was not.

I also tested the prediction that eelgrass would dampen temporal variation in advection and turbulent mixing caused by variable tides and winds.

\section{MATERIALS AND METHODS}

Mass transport in eelgrass beds was measured with a dye-tracking technique developed by oceanographers (e.g. Okubo 1971) and modified for use at smaller spatial and temporal scales by Koehl et al. (1987, 1988, 1993). Briefly, boluses of dye released into the water column are photographed at timed intervals to measure the horizontal rate of translation of the centroid of the dye (advection) and the horizontal rate of spread of the dye (turbulent mixing). Field procedures and analysis of these dye blobs are explained in detail below.

Study sites. Two bays were used for these measurements.

(1) False Bay is located on San Juan Island in Puget Sound $\left(48^{\circ} 29^{\prime} N, 123^{\circ} 1^{\prime} \mathrm{W}\right)$. It is a shallow, protected embayment that contains discrete eelgrass beds separated by sand bars near the mouth of the bay. Measurements were made in False Bay on 6 days in June and July 1989. Two distinct eelgrass beds were chosen for study. Flooding tide flowed through the 'near mouth' bed across a sand bar and into the 'within bay' bed (Fig. 1a). Sites without eelgrass were located in the sand flats 3 to $5 \mathrm{~m}$ upstream from each eelgrass bed. In general, areas with eelgrass were in depressions whereas areas without eelgrass were sand bars. Care was taken to release dye at similar water depths inside and outside of the grass beds. The 'near mouth' and 'within bay' beds were oriented perpendicular to the tidal currents and had the following dimensions: $39 \times$ $17 \mathrm{~m}$ and $95 \times 50 \mathrm{~m}$, respectively.

(2) Tomales Bay, located $50 \mathrm{~km}$ north of San Francisco, is a long narrow bay with extensive eelgrass beds along much of its eastern shore. The study area consisted of nearly continuous eelgrass approximately $2 \mathrm{~km}$ north of Marshall $\left(38^{\circ} 12^{\prime} \mathrm{N}, 122^{\circ} 51^{\prime} \mathrm{W}\right)$. Experiments were performed in Tomales Bay on 10 days in June, July and August of 1990, 1991 and 1992. Within the grass meadow 2 sites that were approximately $110 \mathrm{~m}$ apart were chosen for study (Fig. 1b). Because this study area has nearly continuous eelgrass cover, dye releases outside eelgrass were made in 2 small areas without eelgrass (ca $30 \mathrm{~m}^{2}$ ) located within the larger expanse of eelgrass. Larger unvegetated areas just west of the grass beds were not used because they were substantially deeper than the eelgrass sites, while unvegetated areas to the east of the grass beds were too shallow.

In each grass bed, I determined the average density of shoots and the length of the longest leaf per shoot to the nearest centimeter in ten $0.0625 \mathrm{~m}^{2}$ quadrats (Table 1). In False Bay the quadrats were placed haphazardly in 2 rows extending the length of the grass beds, while in Tomales Bay the quadrats were placed 
Fig. 1 Stylized diagrams of the study sites in (a) False Bay and (b) Tomales Bay. Areas with eelgrass are stippled and unvegetated areas are white. In Tomales Bay eelgrass beds continue beyond the edge of the drawing to the southeast and northwest. Position of the shoreline is approximate in both bays. Sampling locations within the grass beds are marked by dots ( $\bullet$ ) and those outside grass beds are marked by asterisks ( $\star$ ). Directions of flooding tide and wind are marked with solid and dashed arrows, respectively. Dye releases outside of grass beds were made at comparable depths to dye releases made inside grass beds. See 'Methods' for details about study locations a) False Bay

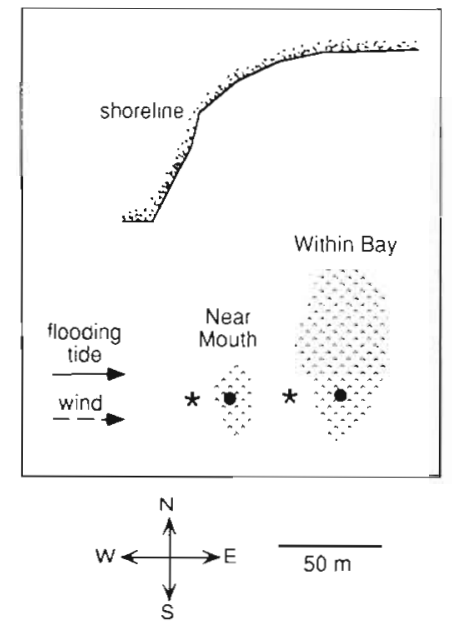

b) Tomales Bay

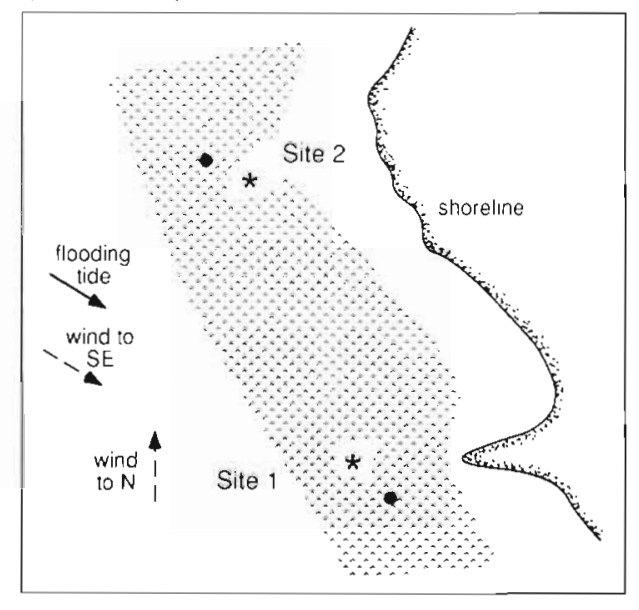

systematically every $6 \mathrm{~m}$ along 2 parallel transect lines placed 5 m apart.

Field measurements of mass transport processes. Dye was released during flooding tide by spearing or cutting small balloons ( $5 \mathrm{~cm}$ long) filled with a solution of fluorescein $\left(3 \mathrm{~g} \mathrm{l}^{-1}\right)$ in sea water. Rubber bands around stakes driven into the sediment held the balloons at 2 heights in the water column: in the middle of the eelgrass canopy or just above the canopy. The midcanopy and above-canopy release heights ranged from 30 to $45 \mathrm{~cm}$ and 70 to $90 \mathrm{~cm}$, respectively, in False Bay, and 10 to $25 \mathrm{~cm}$ and 30 to $45 \mathrm{~cm}$, respectively, in Tomales Bay. Dye releases were made at comparable depths inside and outside of eelgrass. Total water depths in False Bay ranged from 70 to $150 \mathrm{~cm}$ and in Tomales Bay from 20 to $92 \mathrm{~cm}$. Dye releases were made at very shallow depths in Tomales Bay $(<40 \mathrm{~cm})$ to compare flow through a canopy that filled the water column, compared with flow through a canopy that did not reach the surface of the water. The direction of water flow was determined before each run by tracking suspended debris or a small bolus of the fluorescein dye solution released from a syringe. The $35 \mathrm{~mm}$ camera was oriented perpendicular to the direction of dye movement. The photographer, who stood on a sub-

Table 1. Average density of shoots and average maximum leaf length at each site in each bay. $( \pm \mathrm{SD})$

\begin{tabular}{|lrc|}
\hline & Density $\left(\right.$ shoots $\left.\mathrm{m}^{-2}\right)$ & Max. leaf length $(\mathrm{m})$ \\
\hline False Bay & & \\
Near mouth & $173( \pm 69)$ & $0.72( \pm 0.29)$ \\
Within bay & $133( \pm 75)$ & $0.83( \pm 0.28)$ \\
Tomales Bay & & \\
Site 1 & $330( \pm 55)$ & $0.35( \pm 0.11)$ \\
Site 2 & $242( \pm 76)$ & $0.34( \pm 0.15)$ \\
\hline
\end{tabular}

merged platform 0.26 to $0.57 \mathrm{~m}$ above the substratum, was positioned 2 to $5 \mathrm{~m}$ away from the dye-release point. The camera remained in a fixed position and orientation during each run. The dye-release point was positioned on one edge of the field of view of the camera. The photographer began taking pictures when the dye balloon burst and thereafter at timed intervals until the dye blob reached the opposite edge of the field of view of the camera. The maximum size of each dye blob in the direction of current ranged from 1.5 to $4 \mathrm{~m}$. The interval between pictures varied from 3 to $15 \mathrm{~s}$. This interval was determined such that there would be typically 5 to 8 pictures taken during each dye release. The depth of the water was measured with a ruler to the nearest centimeter after each dye release.

Measurements of wind and tidal currents. Wind velocity was measured before and after each series of dye measurements on a given sampling date. Wind velocity was measured at $1.5 \mathrm{~m}$ above the ground near the edge of the water using an anemometer (Kurz model no. 440 in 1989 and 1990, model no. 443 in 1991 and 1992) at each study site. The wind speed used was the median value estimated by eye after observing the range of wind speeds which occurred during approximately 1 min of sampling.

NOAA tide tables were used to determine the water height at mean low low tide for each day on which dye measurements were made. It was assumed that the lower the mean lower low water height, the greater the amount of tidal exchange.

I measured current velocity inside and outside of grass beds in Tomales Bay to compare: (1) instantaneous velocities with the advective velocities measured using dye releases and (2) turbulence intensity values in the field with those measured in a flume (Gambi et al. 1990). Using a flow probe (MarshMcBirney model 511) I measured current velocity in 
$t_{1}$

$t_{2}$

$t_{3}$

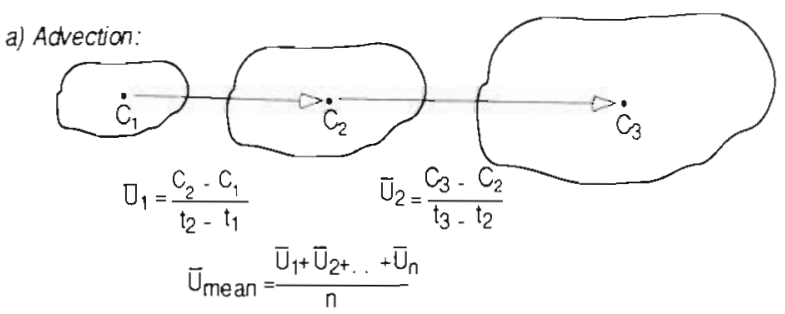

b) Turbukent Mixing:
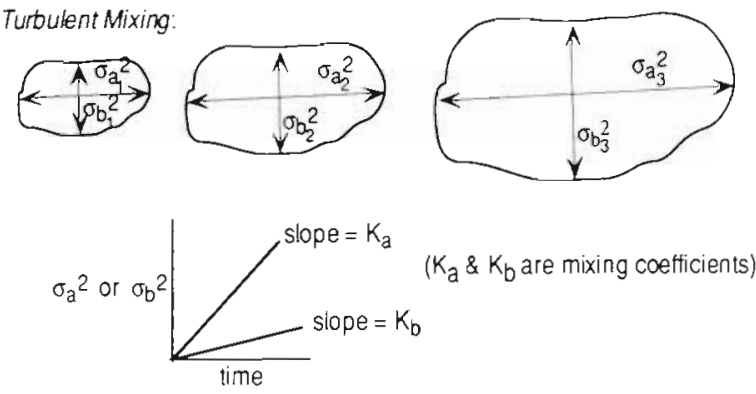

Fig. 2. Calculation of advection and turbulent mixing from $a$ series of pictures of a dye blob at 3 successive time intervals $\left(t_{1}, t_{2}, t_{3}\right)$. (a) Advective velocities $\left(\bar{U}_{1}, \bar{U}_{2}, \bar{U}_{3}\right)$ are calculated from the distance the centroid $(C)$ moves per time interval. Average advective velocity, $\bar{U}_{\text {menn }}$ is calculated from all advective velocities of a single dye blob over time. (b) The variance, $\sigma_{a}{ }^{2}$, of the blob along the axis of greatest spread and the variance, $\sigma_{b}{ }^{2}$, along the axis perpendicular to the first axis are shown on each diagram of the dye blob as it expands. Mixing coefficient $\left(K_{\mathrm{a}}\right.$ or $\left.K_{b}\right)$ is the slope of the regression of each variance, $\sigma_{a}{ }^{2}$ or $\sigma_{b}{ }^{2}$, plotted as a function of time within a single dye blob run

Tomales Bay on 4 days. The flow probe was placed 20 to $30 \mathrm{~cm}$ above the substratum within the canopy or in unvegetated areas at the same height. The flow meter was set with a time constant of $0.2 \mathrm{~s}$ which corresponds to a cut-off frequency of ca $0.8 \mathrm{~Hz}$. The flow meter output was recorded on a chart recorder (Soltec Primeline model \#6723). Water velocities were recorded for
2 min intervals at least twice inside and outside of eelgrass on each sampling date.

Data analysis. The data were analyzed using software developed by G. Dairiki (for details see Koehl et al. 1993). The photographs of dye blobs were projected onto a digitizing pad (Jandel Scientific model no. 2210) interfaced with an IBM-compatible computer, and the perimeter of each blob was traced. The software identified the $x$ and $y$ coordinates for a grid of evenly spaced points within each blob, correcting for parallax. Advective velocity $(\bar{U})$ was calculated from the positions of the centroid of the blob between successive pictures (Fig. 2). Turbulent mixing was determined by calculating the rate of spread in 2 horizontal dimensions of a dye blob at successive times (Fig. 2). To determine the rate of spread of the dye even as it rotated in space, a principal components analysis was used (Berenson et al. 1983). This analysis used all of the $x$ and $y$ coordinates of each blob to determine the axis of greatest spread, the first principle component (axis ' $a$ '), and the axis perpendicular to the first axis which has the second greatest amount of spread (axis 'b'). The eigenvalues of the first and second principle components are a measure of the variance (i.e. the spread) of each blob in the ' $a$ ' and ' $b$ ' directions. The slope of the line of the eigenvalues in the ' $a$ ' and ' $b$ ' directions plotted as a function of time within a dye blob run is the mixing coefficient in each direction $\left(K_{a}\right.$ and $\left.K_{b}\right)$.

Continuous velocity tracings from the flow meter were sampled at $1 \mathrm{~s}$ intervals using a digitizing pad (Jandel Scientific model no. 2210). From these tracings, I calculated mean velocity and turbulence intensity, where the latter is defined as in Gambi et al. (1990):

$$
\begin{gathered}
\text { turbulence } \\
\text { intensity }
\end{gathered}=\frac{\text { standard deviation of velocity }}{\text { mean velocity }} \times 100
$$

All statistical analyses in this study were performed using StatView v. 4.02 (Haycock et al. 1993).

Table 2. Average advective velocities and mixing coefficients $\left(K_{\dot{a}}\right)$ observed $n$ False Bay and Tomales Bay. Mean \pm SD is followed by range (in parentheses) and number of observations. Dye blobs were released at 2 heights (mid-canopy and above canopy) inside and outside of eelgrass beds

\begin{tabular}{|c|c|c|c|c|c|c|c|c|}
\hline & \multicolumn{4}{|c|}{ Advective velocity $\left(\mathrm{m} \mathrm{s}^{-1}\right) \times 10^{-2}$} & \multicolumn{4}{|c|}{ Mixıng coefficient $\left(\mathrm{m}^{2} \mathrm{~s}^{-1}\right) \times 10^{-3}$} \\
\hline & \multicolumn{2}{|c|}{ Inside } & \multicolumn{2}{|c|}{ Outside } & \multicolumn{2}{|c|}{ Inside } & \multicolumn{2}{|c|}{ Outside } \\
\hline & $\begin{array}{l}\text { Mid- } \\
\text { canopy }\end{array}$ & $\begin{array}{l}\text { Above- } \\
\text { canopy }\end{array}$ & $\begin{array}{c}\text { Mid- } \\
\text { canopy }\end{array}$ & $\begin{array}{l}\text { Above- } \\
\text { canopy }\end{array}$ & $\begin{array}{c}\text { Mid- } \\
\text { canopy }\end{array}$ & $\begin{array}{l}\text { Above- } \\
\text { canopy }\end{array}$ & $\begin{array}{l}\text { Mid- } \\
\text { canopy }\end{array}$ & $\begin{array}{l}\text { Above- } \\
\text { canopy }\end{array}$ \\
\hline $\begin{array}{l}\text { False } \\
\text { Bay }\end{array}$ & $\begin{array}{c}2.1 \pm 1.0 \\
(1.0 \text { to } 3.6) \\
n=8\end{array}$ & $\begin{array}{c}42 \pm 2.2 \\
(1.1 \text { to } 8.0) \\
n=10\end{array}$ & $\begin{array}{c}3.5 \pm 1.9 \\
(0.94 \text { to } 7.8) \\
n=12\end{array}$ & $\begin{array}{c}3.9 \pm 0.90 \\
(2.8 \text { to } 5.2) \\
n=8\end{array}$ & $\begin{array}{c}4.1 \pm 3.2 \\
(1.4 \text { to } 10) \\
n=8\end{array}$ & $\begin{array}{c}5.8 \pm 5.4 \\
(1.5 \text { to } 18\} \\
n=10\end{array}$ & $\begin{array}{c}4.4 \pm 3.6 \\
(0.51 \text { to } 13) \\
n=12\end{array}$ & $\begin{array}{c}3.2 \pm 2.2 \\
(1.2 \text { to } 6.6) \\
n=8\end{array}$ \\
\hline $\begin{array}{l}\text { Tomales } \\
\text { Bay }\end{array}$ & $\begin{array}{c}2.1 \pm 1.4 \\
(0.48 \text { to } 4.8) \\
n=12\end{array}$ & $\begin{array}{c}5.7 \pm 1.9 \\
(2.2 \text { to } 9.8) \\
n=10\end{array}$ & $\begin{array}{c}4.3 \pm 3.5 \\
(0.81 \text { to } 12) \\
n=17\end{array}$ & $\begin{array}{c}2.4 \pm 1.5 \\
(0.33 \text { to } 4.6) \\
n=10\end{array}$ & $\begin{array}{c}5.0 \pm 4.5 \\
(0.12 \text { to } 14) \\
n=11\end{array}$ & $\begin{array}{c}20 \pm 21 \\
(4.3 \text { to } 66) \\
n=8\end{array}$ & $\begin{array}{c}14 \pm 22 \\
(0.20 \text { to } 83) \\
n=17\end{array}$ & $\begin{array}{c}6.7 \pm 6.5 \\
(0.77 \text { to } 19) \\
n=9\end{array}$ \\
\hline
\end{tabular}




\section{RESULTS}

The ranges of advective velocities and turbulent mixing coefficients observed in Tomales Bay and False Bay are presented in Table 2. Typical advective velocities in both of these bays are only 0.03 to $0.04 \mathrm{~m} \mathrm{~s}^{-1}$ (Table 2).

Horizontal mixing was nearly always anisotropic. $K_{\mathrm{a}}$ was on average 6 times greater than $K_{\mathrm{b}}$, therefore I focused on $K_{\mathrm{a}}$ throughout these analyses.

\section{Effect of eelgrass canopies on mass transport}

I compared dye blobs taken within $30 \mathrm{~min}$ of each other inside eelgrass beds and in areas without eelgrass at similar water depths using a Wilcoxon Signed Rank Test (Table 3). Due to the temporal variability in advection and mixing in these systems, statistical differences between flow inside and outside of grass beds was only observed for temporally paired data. Advective velocities were greater in areas without eelgrass than in eelgrass at the mid-canopy height in both bays. In contrast, flow was faster above the eelgrass canopy than it was at the same height in areas without eelgrass in Tomales Bay. However, this effect was not observed in False Bay. The mixing coefficient $\left(K_{a}\right)$ was not different within eelgrass beds relative to areas without eelgrass; however, there was greater mixing above the canopy in Tomales Bay than there was at the same height in areas without eelgrass (Table 3).

Although advection outside eelgrass was greater than inside eelgrass, it is possible that the extent of this effect is dependent upon the canopy height with respect to the depth of the water. I found there was greater advection in areas without eelgrass when the

Table 3. Effect of eelgrass on the advective velocity and mixing coefficient $\left(K_{\mathrm{a}}\right)$ in False Bay and Tomales Bay. Paired dye releases were made inside and outside of a grass bed and then compared using a Wilcoxon Signed Rank Test ( $\mathrm{n}=14$ pairs in each bay). Paired comparisons that were different at the $p<0.05$ level indicate whether greater mass transport occurred inside or outside of a grass bed. ns: nonsignificant differences

\begin{tabular}{|lcc|}
\hline & False Bay & Tomales Bay \\
\hline Advective velocity $\left(\mathrm{m} \mathrm{s}^{-1}\right)$ & & \\
Mid-canopy height & Outside $>$ Inside & Outside $>$ Inside \\
Above-canopy height & $n s$ & Inside $>$ Outside \\
Mixing coefficient $\left(\mathrm{m}^{2} \mathrm{~s}^{-1}\right)$ & & \\
Mid-canopy height & $\mathrm{ns}$ & $\mathrm{ns}$ \\
Above-canopy height & $\mathrm{ns}$ & Inside $>$ Outside \\
\hline
\end{tabular}

Table 4. Effect of water depth on advective velocities inside relative to outside of eelgrass beds in Tomales Bay. Mean advective velocity $\left(\mathrm{m} \mathrm{s}^{-1}\right) \pm S D$ is presented. Significance for a Mann-Whitney $U$ is provided at the bottom of each column

\begin{tabular}{|c|c|c|}
\hline & $\begin{array}{l}\text { Water } \\
\text { depth }\end{array}=\begin{array}{l}\text { Canopy } \\
\text { height }\end{array}$ & $\begin{array}{l}\text { Water } \\
\text { depth }\end{array}>\begin{array}{l}\text { Canopy } \\
\text { height }\end{array}$ \\
\hline Inside & $\begin{array}{c}2.6 \times 10^{-2} \pm 2.8 \times 10^{-3} \\
(n=4)\end{array}$ & $\begin{array}{c}1.9 \times 10^{-2} \pm 1.7 \times 10^{-2} \\
(\mathrm{n}=8)\end{array}$ \\
\hline Outside & $\begin{array}{c}7.5 \times 10^{-2} \pm 4.0 \times 10^{-2} \\
(n=6)\end{array}$ & $\begin{array}{c}2.5 \times 10^{-2} \pm 1.3 \times 10^{-2} \\
(\mathrm{n}=11)\end{array}$ \\
\hline p-value & 0.02 & 0.28 \\
\hline
\end{tabular}

water depth equaled the adjacent canopy height than there was when the water depth was greater than the canopy height (Table 4).

\section{Effect of an upstream grass bed on flow through a downstream grass bed}

In the physically discrete grass beds in False Bay, I found that the presence of a grass bed significantly reduced the advective velocities and mixing coefficients at downstream sites (Table 5). This result may have been due in part to the width of the bay being slightly narrower at the upstream site (Fig. 1a). Thus by the law of conservation of mass, flow would go faster through the narrower region of the bay which included the upstream grass bed.

A similar comparison was not possible in the nearly continuous grass beds in Tomales Bay.

\section{Interactions between eelgrass and variations in wind speed and tidal exchange}

Wind speed varied from 1 to $4 \mathrm{~m} \mathrm{~s}^{-1}$ in False Bay and 1 to $10 \mathrm{~m} \mathrm{~s}^{-1}$ in Tomales Bay. The water heights at

Table 5. Average \pm standard deviation of the advective velocity $\left(\mathrm{m} \mathrm{s}^{-1}\right)$ and mixing coefficient $\left(\mathrm{m}^{2} \mathrm{~s}^{-1}\right)$ in the 2 grass beds in False Bay. Significance for a Mann-Whitney $U$ is provided at the bottom of each column

\begin{tabular}{|lcc|}
\hline Advective velocity & Mixing coefficient \\
\hline Near mouth $(\mathrm{n}=20)$ & $\begin{array}{c}4.1 \times 10^{-2} \\
\left( \pm 1.9 \times 10^{-2}\right)\end{array}$ & $\begin{array}{c}5.9 \times 10^{-3} \\
\left( \pm 4.6 \times 10^{-3}\right)\end{array}$ \\
Within bay $(\mathrm{n}=18)$ & $\begin{array}{c}2.8 \times 10^{-2} \\
\left( \pm 1.4 \times 10^{-2}\right)\end{array}$ & $\begin{array}{c}2.9 \times 10^{-3} \\
\left( \pm 1.6 \times 10^{-3}\right)\end{array}$ \\
p-value & 0.04 & 0.03 \\
\hline
\end{tabular}


Table 6. Correlations of mass transport with the amount of tidal exchange and with wind speed. Each cell in the table is a correlation (Kendall's rank correlation, $\tau$ ) of a mass transport parameter [advective velocity $\left(\mathrm{m} \mathrm{s}^{-1}\right)$ or mixing coefficient $\left(\mathrm{m}^{2} \mathrm{~s}^{-1}\right)$ ] and a physical factor (amount of tidal exchange or wind speed). Correlations are further subdivided by whether the measurements were made inside or outside of an eelgrass bed. Statistically significant correlations are followed by a symbol representing the probability, explained below

\begin{tabular}{|c|c|c|c|c|}
\hline & \multicolumn{2}{|c|}{ False Bay } & \multicolumn{2}{|c|}{ Tomales Bay } \\
\hline & $\begin{array}{l}\text { Tidal } \\
\text { exchange }\end{array}$ & $\begin{array}{l}\text { Wind } \\
\text { speed }\end{array}$ & $\begin{array}{c}\text { Tidal } \\
\text { exchange }\end{array}$ & $\begin{array}{l}\text { Wind } \\
\text { speed }\end{array}$ \\
\hline \multicolumn{5}{|c|}{ Advective velocity } \\
\hline Inside & $-0.33^{\circ}$ & 0.13 & -0.25 & -0.09 \\
\hline Outside & $-0.57 \cdots$ & $0.45 \cdots$ & $-0.25^{*}$ & 0.10 \\
\hline \multicolumn{5}{|c|}{ Mixing coeffificient } \\
\hline Inside & $-0.33^{*}$ & 0.21 & -0.06 & -0.02 \\
\hline Outside & $-0.54^{\cdots}$ & $0.48^{\cdots}$ & $-0.41 \cdots$ & $0.25^{\ddagger}$ \\
\hline \multicolumn{5}{|c|}{${ }^{*} \mathrm{p}<0.10 ; \cdot \mathrm{p}<0.05 ; \cdot \mathrm{p}<0.01$} \\
\hline
\end{tabular}

mean lower low water ranged from -0.82 to $-0.5 \mathrm{~m}$ in False Bay and -0.61 to $0.55 \mathrm{~m}$ in Tomales Bay.

In general, in areas without eelgrass there was a significant correlation of mass transport with both wind velocity and the amount of tidal exchange (Table 6). The correlations of mass transport with tidal exchange were negative because the greatest amount of tidal exchange was assumed to occur when the water height at mean lower low water was lowest (see 'Methods'). The correlations of mass transport with both wind and tidal exchange were stronger in False Bay than in Tomales Bay. This difference between the bays may have been due to direction of the wind relative to tidal flow. In False Bay, the direction of the wind and of the tidal currents coincided on all sampling days, whereas in Tomales Bay the tide flooded toward the southeast while the wind blew either to the southeast or to the north (Fig. 1). However, when these correlations were performed separately for each wind direction observed in Tomales Bay, there were no substantial differences from the analysis in which both wind directions were pooled, indicating that variation in wind direction did not explain the lower correlations in Tomales Bay relative to False Bay.

In contrast to areas without eelgrass, there typically was little correlation of mass transport with wind speed or the amount of tidal exchange within eelgrass beds in either bay. These results suggest that eelgrass beds dampen variation in water flow caused by varying wind and tidal currents.

In Tomales Bay when the wind and the tide were in the same direction the effect of eelgrass on mass transport differed from when the wind and tide directions
Table 7. Effect of wind direction on the advective velocity $\left(\mathrm{m} \mathrm{s}^{-1}\right)$ and the mixing coefficient $\left(\mathrm{m}^{2} \mathrm{~s}^{-1}\right)$ inside and outside of eelgrass beds in Tomales Bay. I used a Mann-Whitney $U$ test to compare days in which the wind blew in the same direction as the incoming tidal currents (to the southeast) with days in which the wind blew to the north. ns: not significant

\begin{tabular}{lcc|} 
& Advective velocity & Mixing coefficient \\
\hline Inside $(\mathrm{n}=22)$ & $\mathrm{ns}$ & $\mathrm{SE} \geq \mathrm{N}^{\ddagger}$ \\
Outside $(\mathrm{n}=27)$ & $\mathrm{SE}>\mathrm{N}^{*}$ & $n \mathrm{~S}$ \\
${ }^{\ddagger} \mathrm{p}<0.10 ; \cdot \mathrm{p}<0.05$ & & \\
\hline
\end{tabular}

did not coincide (Table 7 ). In areas without eelgrass, advective velocities were greater when the wind and tide directions coincided relative to when the wind and tide directions did not coincide. In contrast, inside eelgrass beds there was no difference in the advective velocity when the wind and tide directions coincided relative to when the wind and tide directions did not coincide. In addition, there was no difference in turbulent mixing in areas without eelgrass when the wind and tide directions coincided relative to when the directions did not coincide. Conversely, there was slightly greater turbulent mixing inside eelgrass when the wind and tide directions coincided relative to when they did not.

\section{Effect of eelgrass on instantaneous velocity and turbulence intensity in Tomales Bay}

There were no significant differences in the instantaneous velocity (Wilcoxon Signed Rank test, $\mathrm{p}=0.48$ ) or turbulence intensity (Wilcoxon Signed Rank test, $\mathrm{p}=0.33$ ) of flow through areas with and without eelgrass canopies (Table 8 ). The range of velocities measured with a current meter are similar to the advective velocities measured with dye blobs (compare Tables $2 \& 8$ )

Table 8. Mean and range (in parentheses) of the velocities $\left(\mathrm{m} \mathrm{s}^{-1}\right)$ and turbulence intensities measured inside and outside of eelgrass beds in Tomales Bay (where turbulence intensity $=($ standard deviation of velocity $/$ mean velocity $) \times 100]$

\begin{tabular}{|ccc|}
\hline & Velocity & Turbulence intensity \\
\hline $\begin{array}{l}\text { Inside } \\
(\mathrm{n}=14)\end{array}$ & $\left(1.0 \times 10^{-2}\right.$ to $\left.6.2 \times 10^{-2}\right)$ & $\left(4.9 \times 10^{0}\right.$ to $\left.8.4 \times 10^{1}\right)$ \\
& & $3.1 \times 10^{1}$ \\
Outside & $2.8 \times 10^{-2}$ & $5.1 \times 10^{1}$ \\
$(\mathrm{n}=9)$ & $\left(1.1 \times 10^{-2}\right.$ to $\left.5.3 \times 10^{-2}\right)$ & $\left(1.5 \times 10^{1}\right.$ to $\left.2.1 \times 10^{2}\right)$ \\
\hline
\end{tabular}




\section{DISCUSSION}

\section{Differences between False Bay and Tomales Bay}

Although I chose 2 sluggish-flow habitats, False Bay and Tomales Bay, in which to study mass transport through eelgrass, I found many differences between the flow through eelgrass in these 2 bays. These differences may stem from at least 3 factors: (1) there were greater extremes in wind and tide conditions during sampling in Tomales Bay than in False Bay, (2) during my study periods there were 2 predominant wind directions in Tomales Bay, but only 1 in False Bay, and (3) the grass beds in False Bay were discrete and separated by sand bars, while the grass beds in Tomales Bay were nearly continuous (Fig. 1).

The observation of faster flow over the canopy (skimming flow sensu Morris 1955) at the location with continuous eelgrass (Tomales Bay) but not at the location with discrete eelgrass beds (False Bay) may be due to this difference in grass bed spatial arrangement (Table 3). Water must flow around the eelgrass beds, through the eelgrass or over the top of the canopy. Since the grass beds in False Bay are surrounded by sand bars, the water will encounter less resistance to flow by moving around the eelgrass rather than through it. In contrast, the eelgrass cover is nearly continuous in Tomales Bay, increasing the likelihood that water will move over the top of the canopy causing skimming flow. In grass beds in faster currents $>30 \mathrm{~cm}$ $\mathrm{s}^{-1}$ ), flexible seagrass shoots bend over, becoming prone along the substratum, thereby redirecting flow over the eelgrass canopy and enhancing skimming flow (Scoffin 1970, Fonseca et al. 1982, 1983). In the sluggish currents experienced in my study, substantial bending of the shoots in flow did not occur, thus there was probably little contribution of shoot bending to skimming flow.

\section{Comparisons with studies in dense eelgrass beds and fast current flow}

The effects of eelgrass canopies on flow in this field study were very modest relative to the effects reported in previous flume studies (Fonseca et al. 1982, Gambi et al. 1990).

Fonseca et al. (1982) found that the presence of an eelgrass canopy substantially reduced current flow relative to outside the canopy in a flume. They measured flow reduction by the canopy at flow speeds ranging from 0.10 to $0.40 \mathrm{~m} \mathrm{~s}^{-1}$ and found maximum flow reduction at a current velocity of $0.24 \mathrm{~m} \mathrm{~s}^{-1}$, a current speed substantially higher than those observed in Tomales Bay or False Bay. Yet they also found that as ambient current velocity decreased to as low as $0.12 \mathrm{~m}$ $\mathrm{s}^{-1}$, the amount of flow reduction by eelgrass also decreased substantially, scaling to ambient velocities entering the bed. Therefore the modest effect of eelgrass on ambient current velocity observed in Tomales Bay and False Bay at very low current speeds may support the findings of Fonseca et al. (1982).

Gambi et al. (1990) found flow reduction within an eelgrass canopy and flow acceleration over the canopy (skimming flow) at a current velocity of only $0.05 \mathrm{~m} \mathrm{~s}^{-1}$ in a flume. In their study, the eelgrass bed was only $0.15 \mathrm{~m}$ wide in the middle of a flume $0.75 \mathrm{~m}$ wide. Therefore, their results should be more comparable to the isolated grass beds found in False Bay than to the continuous eelgrass habitat found in Tomales Bay. The observation of skimming flow in the flume and not in False Bay may be related to the fact that Gambi et al.'s (1990) lowest shoot density was 2 to 3 times greater than that found in False Bay. Therefore the shoot densities in False Bay may be below the density necessary to cause skimming flow (Nowell \& Church 1979). Similarly, Eckman (1983) observed no skimming flow over salt marsh grass mimics at a similar density to the eelgrass in False Bay. However, direct comparisons between Nowell \& Church's (1979) and Eckman's (1983) study and the current study are likely not valid because their studies are based on short $(\sim 1 \mathrm{~cm})$, rigid structures (Legos and soda straws) whereas eelgrass is 30 to $100 \mathrm{~cm}$ long, flattened and flexible.

Other field studies have also found reduced current speeds within seagrass canopies in slower ambient flow habitats (Peterson et al. 1984, Ackerman 1986. Koch 1993).

\section{Turbulence within plant canopies}

Previous studies have shown that underwater plant canopies can either attenuate low frequency turbulence and generate high frequency turbulence (Anderson \& Charters 1982, Ackerman \& Okubo 1993, Koch 1993), reduce ambient turbulence levels in general (Eckman et al. 1989) or generate turbulence relative to ambient levels (Gambi et al. 1990). In this study, I found no difference in the turbulent mixing coefficient inside relative to outside eelgrass beds in paired observations. These results may differ from previous studies due to different measurement techniques, different scales of measurement and/or differences in the plant canopies and habitats. Many of the past studies on turbulence have focused on long temporal measurements (tens of minutes to hours) made at a point in space, whereas in my study I used a short temporal scale (seconds to minutes) and a larger spatial scale (tens of centimeters to meters). Yet when I made measurements of 
turbulence intensity using a flow meter like Gambi et al. (1990), I still found no difference in turbulence intensity inside relative to outside of eelgrass beds (Table 8). However, my ability to detect high frequency turbulence that may have been generated by the fluttering of eelgrass leaves was limited by my $1 \mathrm{~Hz}$ sampling rate. Even with this limitation, the values of turbulence intensity for eelgrass in the field were larger and more variable than those from Gambi et al.'s (1990) flume study (range of field values: 5 to 212 , average range of flume values: 5 to 30 ) even under lower current velocities. These differences in turbulence intensity may be related to the difference in size of the plants in these 2 studies: Tomales Bay leaves were $35 \mathrm{~cm}$ long while Gambi et al.'s (1990) leaves were $12 \mathrm{~cm}$ long. In addition, my study is distinct from the other studies on turbulence within plant canopies due to the low density of shoots as well as the sluggish currents. It seems likely that plant canopies affect turbulence at different scales and that these effects will be dependent upon the magnitude of the currents, the density of the canopy and the amount of the flapping of the leaves.

The dampening of variation in mixing within eelgrass beds as a function of varying winds and tides relative to ambient conditions observed in this study (Table 6) has also been observed within kelp canopies (Eckman et al. 1989)

\section{Biological consequences of flow reduction through canopies}

Flow reduction within plant canopies as demonstrated in this study can have important biological effects on the organisms within the canopy. For instance, photosynthesis may be limited in slow flows by gas exchange rates along the surface of plants (Wheeler 1980, Fonseca \& Kenworthy 1987, Koehl \& Alberte 1988). However, Koch (1994) found that the presence of epiphytes increased the turbulence in the boundary layer, leading to reduced nutrient limitation in 2 tropical seagrasses even in reduced flows within the canopy. In this study the sparse eelgrass beds in sluggish flows reduced ambient velocities to a much lesser degree than dense eelgrass beds in faster flows It is likely that limitations in carbon uptake would only occur during slack tides.

Reduced flow within a canopy may have a variety of effects on suspension feeders depending on the species and the habitat. These effects include: increased food availability due to an increase in material suspended in the water column (Peterson et al. 1984 . Irlandi \& Peterson 1991), reduced food availability due to depletion by other suspension feeders (Kerswill
1949), either enhanced or reduced particle capture success depending upon the absolute velocity and the organism (Shimeta \& Jumars 1991), and burial due to a higher sedimentation rate (Eckman \& Duggins 1991). Therefore the effects of flow through canopies in these sparse stands and sluggish flow will vary depending upon the organism

The density of larval settlement may vary due to flow reduction within the canopy (Bernstein \& Jung 1979, Jackson 1986, Peterson 1986, Duggins et al. 1990). The results from this study suggest that eelgrass may retard the distance short-lived larvae disperse. I found in a related study that ascidian larvae disperse shorter distances within eelgrass canopies than outside eelgrass (Worcester unpubl.).

In summary, I used a novel approach to the study of flow through eelgrass beds to directly measure mixing within the canopy, rather than estimating mixing from velocity profiles as previous studies have done. I found that eelgrass canopies in slow flow habitats have a small effect on ambient advective velocity and that accelerated mass transport over the canopy is only observed in areas with nearly continuous eelgrass cover, but not in areas with discrete eelgrass beds

The current paradigm of the effects of seagrass beds on ambient flow has been developed from studies that emphasize relatively high current speed environments. This study reveals that some of the predicted interactions between water flow and seagrass hold at low current velocities such as reduced advection within the canopy relative to outside of the canopy; while other predicted interactions between the canopy and flow are either different than expected (i.e. turbulence) or variable depending upon the situation (i.e. skimming flow). These differences from previous studies probably are a result of the absence of bending by the shoots, the low shoot densities and the low ambient velocities. Detailed flume studies at low speeds and shoot densities would augment this study and provide a more complete understanding of the effects of seagrasses on flow and the resultant effects on the biology of organisms within such habitats. Moreover, the low velocities observed in this study occur regularly in fast flow environments near slack tides. Finally, this study provides the first indication that larger scales of bed spatial arrangement need to be considered to understand effects of seagrasses on flow at smaller spatial scales within the bed

Acknowledgements. I thank the many people who helped with the field measurements, especially my participants in the University Research Expeditions Program. I thank the Director of the Fnday Harbor Laboratories for use of the facilities. I especially thank Mımi Koehl and the U. C. Berkeley biomechanics group for advice while completing this project. I also thank Mark Fonseca, Bob Full. Alex Horne, Mimi Koehl Steve 
Moore and 2 anonymous reviewers for helpful comments on the manuscript. This work was supported by the Lerner-Gray Marine Fund of the American Museum of Natural History, Sigma-X1 Grants-in-Aid of Research, the ARCS Foundation and the University Research Expeditions Program to S.W. and NSF Grants OCE85-10834, OCE89-17404, OCE92-17338 and ONR Grant N00014-90-J-1357 to M. Koehl.

\section{LITERATURE CITED}

Ackerman JD (1986) Mechanistic implications for pollination in the marine angiosperm Zostera marina. Aquat Bot 24: $343-353$

Ackerman JD, Okubo A (1993) Reduced mixing in a marine macrophyte canopy. Funct Ecol 7:305-309

Anderson SM, Charters AC (1982) A fluid dynamics study of seawater flow through Gelidium nudifrons. Limnol Oceanogr 27:399-412

Berenson ML, Levine DM, Goldstein M (1983) Intermediate statistical methods and applications: a computer package approach. Prentice-Hall, Inc, Englewood Cliffs, NJ

Bernstein BB, Jung N (1979) Selective pressures and coevolution in a kelp canopy community in southern California. Ecol Monogr 49:335-355

Carpenter RC, Hackney JM, Adey WH (1991) Measurements of primary productivity and nitrogenase activity of coral reef algae in a chamber incorporating oscillatory flow. Limnol Oceanogr 36:40-49

Carpenter RC, Williams SL (1993) Effects of algal turf canopy height and microscale substratum topography on profiles of flow speed in a coral forereef environment. Limnol Oceanogr 38:687-694

Duggins DO, Eckman JE, Sewell AT (1990) Ecology of understory kelp environments. II. Effects of kelps on recruitment of benthic invertebrates. J exp mar Biol Ecol 143:27-45

Eckman JE (1983) Hydrodynamic processes affecting benthic recruitment. Limnol Oceanogr 28:241-257

Eckman JE (1987) The role of hydrodynamics in recruitment, growth, and survival of Argopecten irradians (L.) and Anomia simplex (d'Orbigny) within eelgrass meadows. $\mathrm{J} \exp$ mar Biol Ecol 106:165-191

Eckman JE, Duggins DO (1991) Life and death beneath macrophyte canopies: effects of understory kelps on growth rates and survival of marine, benthic suspension feeders. Oecologia 87:473-487

Eckman JE, Duggins DO, Sewell AT (1989) Ecology of understory kelp environments. I. Effects of kelps on flow and particle transport near the bottom. J exp mar Biol Ecol $129 \cdot 173-187$

Edgar GJ (1990) The influence of plant structure on the species richness, biomass and secondary production of macrofaunal assemblages associated with Western Australia seagrass beds. J exp mar Biol Ecol 137:215-240

Fonseca MS, Fisher JS (1986) A comparison of canopy friction and sediment movement between four species of seagrass with reference to their ecology and restoration. Mar Ecol Prog Ser 29:15-22

Fonseca MS, Fisher JS, Zieman JC, Thayer GW (1982) Influence of the seagrass, Zostera marina L., on current flow. Estuar coast Shelf Sci 15:351-364

Fonseca MS, Kenworthy JW (1987) Effects of current on photosynthesis and distribution of seagrasses. Aquat Bot $27: 59-78$

Fonseca MS, Zieman JC, Thayer GW, Fisher JS (1983) The role of current velocity in structuring eelgrass (Zostera marina L.) meadows. Estuar coast Shelf Sci 17:367-380
Gambi MC, Nowell ARM, Jumars PA (1990) Flume observations on flow dynamics in Zostera marina (eelgrass) beds. Mar Ecol Prog Ser 61:159-169

Ginsburg RN, Lowenstam HA (1958) The unfluence of marine bottom communities on the depositional environment of sediments. J Geol 66:310-318

Haycock K, Roth J, Gagnon J (1993) StatView (v. 4.02). Abacus Concepts, Berkeley, $\mathrm{CA}$

Heck KL, Orth RJ (1980) Seagrass habitats: the roles of habitat complexity, competition, and predation in structuring associated fish and motile macroinvertebrate assemblages. In: Kennedy VS (ed) Estuarine perspectives. Academic Press, New York, p 449-464

Irlandı EA, Peterson CH (1991) Modification of animal habitat by large plants: mechanisms by which seagrasses influence clam growth. Oecologia 87:307-318

Jackson GA (1986) Interaction of physical and biological processes in the settlement of planktonic larvae. Bull mar Sci 39:202-212

Kerswill CJ (1949) Effects of water circulation on the growth of quahaugs and oysters. J Fish Res Bd Can 7:545-551

Koch EW (1993) Hydrodynamics of flow through seagrass canopies: biological, physical, and geochemical interactions. PhD dissertation, University of South Florida, Tampa

Koch EW (1994) Hydrodynamics, diffusion-boundary layers and photosynthesis of the seagrasses Thalassia testudinum and Cymodocea nodosa. Mar Biol 118:767-776

Koehl MAR (1986) Form and function of macroalgae in moving water. In: Givinish TJ (ed) On the economy of plant form and function. Cambridge University Press, Cambridge, p 291-314

Koehl MAR, Alberte RS (1988) Flow, flapping, and photosynthesis of Nereocystis luetkeana: a functional comparison of undulate and flat blade morphologies. Mar Biol 99: $435-444$

Koehl MAR, Powell TM, Dairiki G (1993) Measuring the fate of patches in the water: larval dispersal. In: Levin SA. Powell TM, Steele JH (eds) Patch dynamics. SpringerVerlag, New York, p 50-60

Koehl MAR, Powell TM, Daniel TL (1987) Turbulent transport near rocky shores: implications for larval dispersal. EOS 68:1750

Koehl MAR, Powell TM, Daniel TL (1988) Turbulent transport of marine larvae near rocky shores. Am Zool 28:113A.

Molinier R, Picard J (1952) Recherches sur les herbiers de phanérogames marines du littoral mediterranéen français. Ann Inst Océanogr (Paris) 27:157-234

Morris HH (1955) A new concept of flow in rough conducts. Trans Am Soc Civil Eng 120:373-398

Nowell ARM, Church M (1979) Turbulent flow in a depth-limited boundary layer. J geophys Res 84:4816-4824

Okubo A (1971) Oceanic diffusion diagrams. Deep Sea Res 18:789-802

Orth RJ (1977) The importance of sediment stability in seagrass communities. In: Coull BC (ed) Ecology of marine benthos. University of South Carolina, Columbia, p $281-300$

Orth RJ, Heck KL, van Montfrans J (1984) Faunal communities in seagrass beds: a review of the influence of plant structure and prey characteristics on predator-prey relationships. Estuaries 7:90-102

Peterson CH (1986) Enhancement of Mercenaria mercenaria densities in seagrass beds: is pattern fixed during settlement season or altered by subsequent differential survival? Limnol Oceanogr 31:200-205

Peterson CH, Summerson HC, Duncan PB (1984) The influence of seagrass cover on population structure and indi- 
vidual growth rate of a suspension feeding bivalve, Mercenaria mercenaria. J mar Res 42:123-138

Scoffin TP (1970) The trapping and binding of subtidal carbonate sediments by marine vegetation in Bimini Lagoon, Bahamas. J sedim Petrol 40:249-273

Shimeta J, Jumars PA (1991) Mechanisms and rates of particle capture by suspension feeders. Oceanogr mar Biol A Rev 29:191-257

This article was presented by G. W. Thayer (Senior Editorial Advisor), Beaufort, North Carolina, USA
Wheeler WN (1980) Effects of boundary layer transport on the fixation of carbon by the giant kelp Macrocystis pyrifera. Mar Biol 56:103-110

Wood EJF, Odum WE, Zieman JC (1969) Influence of sea grasses on the productivity of coastal lagoons. In: Castanares A, Phleger FB (eds) Coastal lagoons, a symposium. Universidad Nacional Autonoma de Mexico, Ciudad Universitaria, Mexico, DF, p 495-502

Manuscript first received: December 18, 1994 Revised version accepted: April 27, 1995 